\title{
Identification of Health Disorders a Prison Population
}

\begin{abstract}
Daniel Cândido de Lima1, Ana Eloísa Cruz de Oliveira², Ericka Silva Holmes ${ }^{3}$, Bento Forte de Oliveira Neto ${ }^{4}$, Priscilla Evelly Moreira Brito ${ }^{5}$, Lívia Menezes Borralho ${ }^{6}$, Bueno Callou Bernardo de Oliveira7, Tattiana Dias de Carvalho ${ }^{8}$, Ana Rita Bizerra do Nascimento Ribeiro ${ }^{9}$, Rafaela Jeane Pereira Cunha ${ }^{10}$, João Agnaldo do Nascimento ${ }^{11}$
\end{abstract}

\section{Abstract}

Objectives: to identify the main health problems of the prison population, describe the sociodemographic and health of convicts profile; point the main complaints and more frequent pathologies.

Method: exploratory, descriptive, quantitative and qualitative, held in a maximum security prison. The study sample was composed of 63 convicts, which answer a semi-structured form. For the analysis, there was the simple descriptive statistics and discourse analysis of the collective subject.

Results: the prison population is young, with low educational level and family income, present as the main pathologies skin disorders, respiratory disorders, gastrointestinal, cardiovascular, and infectious diseases.

Conclusions: are numerous health problems presented by the detainees, as well as their complaints ranging from lack of medical care and other health professionals, to the unsanitary conditions in which live, and picture of state failure and the competent bodies.

\section{Keywords}

Health - Prison System; Prison Population; Health Profile; Public Health.
1 Nurse. Student of the Law School of the Federal University of Paraíba. Post graduate in Civil Law, Civil Procedure Law and Consumer Law from the School of Higher Education of Paraíba.*.

2 Nurse. Postgraduate in Occupational Health Nursing. PhD student in Health and Decision Models (PPGMDS).*

3 Nurse. Postgraduate in Family Health. PhD student in Health and Decision Models (PPGMDS/UFPB).*.

4 Nurse. Post graduate in Health at the Federal University of Maranhão. Nurse of the City of Guarabira, Brazil.

5 Nurse. Postgraduate in Occupational Health Nursing Faculty San Francisco Paraíba.*

6 Nurse. Master's Graduate Program in Public Health at the State University of Paraiba.*.

7 Nurse. Postgraduate in Family Health at the University of Pelotas. Nurse of the City of Guarabira, Brazil.

8 Nurse. Post Graduate in Political and health care management with emphasis on matrix support from the Federal University of Paraíba.*.

9 Nurse. Master the Graduate Program in Nursing (PPGENF/UFPB).*

10 Physiotherapist. Post graduated in Family Health at the Federal University of Paraíba.* .

11 Mechanical Engineer. PhD in Statistics, Assistant Professor at the Federal University of Paraíba.*. *: João Pessoa, Brazil.

\section{Contact information:}

\section{Ericka Silva Holmes.} been little studied. With the democratization of our country, the public enemy migrated from questing public order for the burglar, the thief, 
the dealer, through the suburbs, slums and prisons to be despised state action [1, 2]. It is the demographic clipping regarding the prison population that focuses the research line of this study.

According to data from the National Penitentiary Department, in 2014, the national prison population of 579.423 inmates, with a deficit of 231.062 vacancies, and occupancy rate around $161 \%$, distributed in 26 states, and the Federal District [3].

The state of São Paulo is where it has the largest prison population, a total of 219.053 convicts distributed throughout the state, an amount corresponding to about $36 \%$ of the Brazilian population. The state of Minas Gerais and Rio de Janeiro, occupy the second and third, with about 61.286 and 39.321 prisoners, respectively. In contrast, the state of Roraima has only 1.610 people arrested, and the country's region with the lowest number of prisoners [3].

In the state of Paraíba, male and female prison population in 2014 was 9.270 inmates, of which $38 \%$ were pretrial detainees. Have the ability to vacancies in the prison system of this federation unit is only 5.892 beds, which creates a deficit of 3.378 jobs. Added to the calculation of the amount of convicts, prisoners under house arrest for a total of 8 individuals, which ends just 9.278 prisoners and 3.380 deficit beds in Paraiba prison system.

Statistical denounces the serious crisis in the prison system where health is only one of its aspects. Thus, it is worth investigating how to keep health services, rights, and the solutions offered to this special population. Therefore, this study aims to answer the following questions: What are the main health problems? Does the prison system meets the health needs of inmates? What is the socioeconomic status and level of education? What are the main complaints? What are the most diagnosed diseases?

For holistic understanding of the problem, this paper aims to: identify the main health problems of the population studied, describe the profile socio-demographic and health status of inmates; pointing out the main complaints reported and the most frequent pathologies.

\section{Method}

This is a survey of exploratory and descriptive, with quantitative and qualitative approach, held in Prison Romeu Gonçalves Maximum Security Abrantes PB-I and PB-II, Jacarapé district of João Pessoa-PB, in 2013. Its population was composed of 630 inmates confined in the penal institution in question, and the sample of 63 convicts. Therefore, it is noted that the collection was carried out only after approval by the ethics and research committee, after signing of Consent Terms and Clarified and after meeting the inclusion criteria were to participate voluntarily in the research and find recluse in closed regime.

To collect data, it built a form to interview, composed of two parts, the first referring to the sample characterization data and the second related to the proposed objectives. Once collected, the data were analyzed and substantiated by the literature on the matter and had two moments: one for quantitative data, using simple descriptive statistics, presenting the results in graphs, charts and tables, and the qualitative data were arranged as collective subject discourse.

Were considered the ethical aspects of research involving human subjects, recommended by Resolution 466/2012 of the National Health Council, in art. III, which deals with the involvement of research with human beings, as well as, Resolution 311/2007 of the Federal Nursing Council, which deals with the code of ethics of nursing professionals [4]. The study was submitted to the Research Ethics Committee of the Hospital Universitário Lauro Wanderley and approved with protocol number 055/10. 


\section{Results and Discussion}

The results show that all the convicts belong to the male, are aged between 25 and 54 years, and the age cut of 25 to 34 years makes a total of $57.2 \%$. These data lead us to conclude that the large prison population of the prison study is quite young.

Although they represent $32,5 \%$ of the population over 18 years, young males between 18 and 29 years constitute $59,6 \%$ of the prison population in the country. The figures do not show that young people necessarily commit more crimes than other age groups of the population, but which are associated with threatening practices of public security and therefore are prime target of actions aimed at repressing them [5].

Most of the inmates of the criminal house is secluded in a time between 0 and 24, representing $69.8 \%$ of the sample the $0-09$ years where many of these are first-time offenders. The remaining 30.2\% represents a penalty of time more than 10 years, many of these cases recurrence or conviction for successive crimes, raising, its time penalty.

It is observed through the data collected that most convictions from 0 to more than 40 years, precisely $74.6 \%$ of the total, serving sentences of between 0 and 29 years of imprisonment and that, being able to say that this time mainly includes execution of crimes against the person, property and customs, among others.

What also draws attention is the percentage of inmates with longer than 40 years (15.9\%), this reflects convictions Jury Court's jurisdiction crimes, whether governed by extravagant laws. It is known, however, that in Brazil there is no life sentences, but 508 people are sentenced to over 100 years of prison and 2.592 serving sentences totaling between 50 and 100 years [6].

On the level of education of convicts, it is revealed that more than half of respondents (52.5\%), did not get to complete the first phase of elementary school. About this information Dassi [7] found this quite disturbing reality when he states that the level of education of inmates at the time of his imprisonment, the last prison census found that $83 \%$ of São Paulo prison, have only primary education. These data, in a sense, reflect the social reality of Brazil.

Among the coming of Paraiba convicts have several cities, including João Pessoa (15), Campina Grande (13), Sousa (5), Patos (3), Sapé (2), Teixeira (2), Guarabira (1) , Itabaiana (1) Cruz do Espírito Santo (1), Mamanguape (1), São João do Cariri (1), Cuité (1), São José do Ramo (1), Carcerengue (1), Jacaraú (1) Bayeux (1), Esperança (1), Itaporanga (1), Remigio (1), Santa Rita (1), together representing $85,7 \%$.

Crime has grown eight times the paraibana population, according to the state Department of Security and Social Defense (SEDS). Criminal incidents rose $30 \%$ over the past five years, eight times the population, with only $3.48 \%$. João Pessoa is the most violent city, then the order of Cabedelo, Bayeux, Patos, Campina Grande, Santa Rita, Conde, Sousa, Guarabira and Cajazeiras, according to data from the SEDS and the Brazilian Institute of Geography and Statistics [8].

The survey data reveal the true financial situation of the surveyed convicts. Although $77.7 \%$ of them stated to receive a minimum wage as an income source, the practice of organized crime by some of them, even if arrested, mostly theft crimes and trafficking distorts this statement. To Dassi [7], the vicious circle of the subject with the school malformation, unemployment and rising crime are closely linked factors.

With regard to the appearance of pathologies after the arrest, it was observed that that $95.2 \%$ of the study population mentioned the involvement of some disease after they were arrested. It is believed that this event presents relationship with the environment of prisons, which are unfriendly, unhealthy and disseminators of disease.

In this context, Assis [9] describes the portrait of Brazilian and world penitentiaries is composed by overcrowding and precariousness of the cells; for environmental unhealthiness making prisons a con- 
ducive environment for the proliferation of epidemics and contagious diseases. This sad reality can be confirmed by setting the conditions shown in Table 1.

Table 1. Convicts surveyed by type of disease that presented after the arrest, João Pessoa.

\begin{tabular}{|l|l|l|}
\hline \multicolumn{1}{|c|}{ Type of disease after arrest } & $\mathbf{n}$ & $\mathbf{f ~ ( \% )}$ \\
\hline Skin disorders & 23 & 36.5 \\
\hline Respiratory disorders & 20 & 31.7 \\
\hline Infectious Contagious Diseases & 20 & 31.7 \\
\hline Gastrointestinal disorders & 14 & 22.2 \\
\hline Cardiovascular disorders & 13 & 20.6 \\
\hline Osteoarticular disorders & 12 & 19.1 \\
\hline Sexually Transmitted Infections & 09 & 14.3 \\
\hline Dental problems & 07 & 11.1 \\
\hline Endocrine disorders & 03 & 4.8 \\
\hline Mental disorder & 03 & 4.8 \\
\hline Sleep Disorders & 03 & 4.8 \\
\hline Disorders Otological & 02 & 3.2 \\
\hline Ophthalmologic problems & 02 & 3.2 \\
\hline Allergic problems & 02 & 3.2 \\
\hline Urological disorders & 01 & 1.6 \\
\hline Infectious diseases & 01 & 1.6 \\
\hline Others * & 24 & 38.1 \\
\hline & Source: Research data, 2013. \\
\hline
\end{tabular}

Therefore, the analysis of this data reveals alarming information. Skin diseases are the leading diagnoses among those surveyed, accounting for 23 (36.5\%) of them. Mycoses, escabioses boils and are the most prevalent conditions among the skin diseases. The problem is centered around the system in which convicts are and the unhealthy living conditions, as most of these diseases could be prevented with simple cleanliness and hygiene measures. Wash all clothes with boiling water, exposure of these parts to the sun for drying, as well as mattresses, towels and sheets, periodic cleaning of cells and correct medications are simple and effective mea- sures to solve the most skin conditions in prisons.

However, as it is a maximum security prison, restricted access during sunbathing is prohibited to display clothes, mattresses and sheets, contamination and spread of these diseases is almost inevitable, especially in isolated cells, in which neatness is minimal or absent and there is a high turnover of inmates.

Parasitic skin diseases, such as pediculosis, scabies, tungiasis and cutaneous larva migrans (LMC), are very common in poor communities in Brazil. Often the presence of severe and complications resulting infestation. Despite this condition, control programs for these diseases are almost nonexistent, they are often being neglected by both professionals and health authorities and the affected population [10].

Respiratory disorders also represent alarming rates of incidence and prevalence. With a total of 20 (31.7\%) individuals of the population interviewed, the most significant diagnosis of this disorder are: asthma, pneumonia, pharyngitis, flu, productive cough and tiredness. In a survey of prisoners of Manaus, proved similar situations where about $41 \%$ of the inmates had respiratory diseases and $11 \%$, digestive problems [11].

Affecting 20 (31.7\%) of the surveyed inmates, the infectious diseases are the great villains of prisons in general. Diagnoses such as herpes, leprosy and tuberculosis are common mainly to be found in prisons. An aggravating factor to this situation is the large number of inmates confined in a small space and reduced the effective of the prison health situation, becoming thus almost impossible to conduct diagnostic tests on all contacts.

In Brazil, although health professionals related to the prison system consider, for their experience, that TB is a major challenge among the detainees, the magnitude of the problem is little known by the absence, in most Brazilian states, specific monitoring programs epidemiological and fight against TB in the prison population [12]. 
Miranda and Zago [13] portray the origin of the prisoners as to access to health care by claiming that these people are from communities with limited access to health care, especially in relation to primary care, early detection and treatment of disease.

Thus, in general, the main concern is the spread of these diseases to the general population through visits and the return of these prisoners to the social environment. Various infectious diseases such as tuberculosis and AIDS epidemic reached high levels of the Brazilian prison population. By denying proper treatment of prisoners, the prison system not only threatens the lives of these as facilitating the transmission of diseases to the population through conjugal visits and the release of prisoners [11].

Regarding gastrointestinal disorders, it was observed that these are frequent and prevalent in the prison population, being reported by 14 (22.2\%) individuals. Diseases such as hemorrhoids, constipation, pancreatitis, rectal operations and liver and spleen surgery appear in reports of diagnosed diseases among inmates investigated. ulcer and gastritis cases also denote significant values. But the most alarming are the cases of acute diarrhea that are affected, because often a poorly packaged food or out-dated, to be prepared, resulting in inadequate meal consumption, and such cases happen on a large scale can in pavilions to be said about 250 to 350 inmates patients at once.

Cardiovascular problems identified in 13 (20.6\%) subjects, it was observed that the most significant disease in absolute numbers was hypertension. A moved by stress environment where everything becomes a matter of concern and risk of death, it is justified by the figures presented in this study, involving young adults and middle-aged adults. The Ministry of Health complete that in terms of circulatory diseases, most admissions, is due to coronary events (40.5\%), followed by hypertension (18.7\%) [14].

In the case of osteo, 12 of respondents reported having a health problem connected to this system. Deviations column, osteoporosis, back pain, joint pain resulting from repetitive labor, atrophy and limb amputation from firearm shooting are the diagnoses that most appear among the investigated.

Sexually transmitted diseases have always been given attention and care to prevent the spread and contamination among inmates. With the representation of 9 (14.3\%) subjects who reported such diagnoses, this number can extrapolate if there is an active search for cases. Moreover, improper practice of tattoos, the use of shared objects contaminated with secretions and especially unprotected homosexual are the major disseminators of these diseases. Thus, delivery of condoms and prevention guidelines are the activities undertaken in prisons and the treatment of those affected by the disease and who have been diagnosed [15].

Dental problems, although they appeared in low incidence $(7 / 11.1 \%)$, appear more frequent than express these numbers. The Health Executive Management of Paraíba of Prisons has only a mobile unit for dental care for more than eighty prisons throughout the state. The convicts who often can't afford to even hire a lawyer, waiting, without hope, the presence of this mobile unit in the prison where they are being cared for.

The item that appears the name "Other", with 24 (28.1\%) individuals, refers to some specific diagnoses such as hernias, headaches, fever, pain, burns, injuries from knives and firearms and superficial and deep incisions in the skin from the same types of weapons. These diagnoses are often found within the prisons, where gangs exist in the same lead to extreme control of certain strategic points of drug sales in and out of prisons as well, the use of necessary force by police and military agents penitentiaries to contain any uprisings and maintain order and discipline in prisons [11].

The quality of health services that are provided in prisons, $79.4 \%$ of the prison population is not satisfied. The disregard for the health of this population occurs at different levels ranging from the 
lack of power to the complete absence of services, supplies and medical and hospital supplies in these establishments, through lack of physical structure and unsanitary conditions that they are incarcerated.

For qualitative analysis, through the collective subject discourse were achieved four central ideas arranged in Table 2, together with the interviews. It is noteworthy that the presented speeches refer the answers to the following questions present in the form: "Do you think the prison system meets the health needs of inmates? Because?".

It is important to note that the interviews inmates point to different segments of health that are equivalent to the claims of the general population, however, as it is a specific portion of the population with peculiar conditions of confinement, health, nutrition and hygiene, the actions and health services are as important as the free citizen.

Table 2 Central View 01 of the Collective Subject Discourse refers to the lack of medical and dental care in the prison system. Several conferences, debates and seminars to solve this problem have been carried out and shed more focused for resolution of this issue is the privatization of prisons across the country where various federal units took the initiative succeeding.

Table 2. Ideas Central 01, 02, 03, 04 and Collective Subject Discourse, João Pessoa.

\section{Central idea Collective Subject Discourse}

01

It's a little complicated because we do not have adequate medical care without dental care and emergency cases are not met faster

For days I want to talk to the cardiologist Lack of and I can not. The doctor hides to not talk medical care to the people I'm missing breath and I do and dental not care.

We do not have dental care for many years hopefully.

Because I wanted to pull my teeth and hit my head electro.

\section{Central idea \\ Collective Subject Discourse}

02

Many times we get sick we have to be met there where we are." "Only one nurse for every 800 prisoners and is very difficult to escort to the hospital." "Lack of staff health and medicines, procedures materials and above all lack of interest rulers.

Shortage Lack of effective and infrastructure.

of health professionals and wards Lack of adequate infirmary with medical escort and nurses and ambulances disposal.

Lack medicine. Dentist. Medical team. Ambulance. Sick bay. Clinic.

Lack dentist, periodic examinations, effective personnel and equipment.

Team medical social worker psychologist ambulance, medicines.

Lack of a full team of health, lack medicine.

03

Lack of equipment, It's bad because they lack professional instruments equipment

and medication

Lack ambulance, medical staff and medicine Because my lack of sleep medicine.

Lack of medicine, doctor daily.

04

For lack of remedies for various diseases and we have no doctor enough to meet the prison system population. I've witnessed friends die from lack of medical care.

Lack further assistance and interest of the authorities because a lot of people dying wanes. It is a disregard for the health of

Disregard for prisoners us.

the health of prisoners

Good Ta because when we are sick we and attended because we work in the house plus many of our comrades who need not have service.

This terrible does not care.

Because? We get sick and they do not take us to the hospital.

Lack medical, food, everything. 
Kuehne [16] addresses this question by stating that the privatization, whose obstacles are the most spacious, features several favorable aspects, including the significant improvement of medical, dental, psychological and legal, which among other factors, are the main causes of rebellions in prisons around the country.

The women's prisons are also targets of the same problems for the health service prison and are cited by Lima [17] to describe that in relation to these prisons, mistreatment, overcrowding, physical structure, lack of hygiene, lack or medical disability in general, violence and the inadequacy of specific public policies for women are the main factors that leverage the health-disease process in these establishments.

The Central Idea 02 Collective subject discourse points to the issue of inefficient number of health professionals willing to work in these places and the lack of suitable sites to develop health services in prisons example clinics or wards. Fear, low wages and unhealthy conditions of the physical structures are some of the problems faced by these professionals.

A major problem is the lack of health professionals willing to work with detainees in places as hostile and inappropriate for such activity. Fear and low wages are the barriers to physicians, psychologists, nurses and social workers to accept employment. These people need to have a better financial recognition [18]

Oliveira et al [19] depicts the situation within the female prisons stating that access to health care as a right little observed in Brazilian prisons need to be made effective for the care related to women's health prey to succeed. The overcrowding, lack of health professionals, particularly doctors and the structural conditions of the penitentiary system put up as relevant elements in the consolidation of the health of the prison population.

The lack of professional equipment and medication, essential inputs for the development of health services is the Central Idea 03 Collective Subject
Discourse. This context is referenced by Amoy et al. [20] when he states that medical resources, read up clinical, outpatient or hospital are scarce, medical equipment, if any, are obsolete, and, of course, the lack of medicines in sufficient numbers to meet the demand of these units.

The report on incarcerated women in Brazil produced by the National Pastoral Prison [21] reproduces a fact of prey foreign mother and her anguish for lack of medication in the fight against HIV, "A prey in South Africa spent two months believing be HIV-positive and that her daughter had also been infected with HIV. His situation was desperate because neither she nor her daughter were receiving medication, when in fact, there had been a misunderstanding between the doctor and the patient, who did not speak Portuguese."

The Central Idea 04 of the Collective Subject Discourse is the disregard for the health of prisoners. This as old problem as the history of prisons seems to have no solution to the drafting of laws and decrees, as long as there is no social awareness and willingness to change on the part of the community, neglect and discrimination remain part of the daily life of this population as accursed society.

The medical attention in the Brazilian prison system not only presents situations of neglect and failure prisons as well peculiar characteristics to the physical and emotional ailments that incarceration of context, focus with different intensity worsened through no access to prevention practices, treatment and because medical monitoring [21].

The report produced by the National Pastoral Prison [22] entitled: Pena illegal and extrajudicial killing, the question of the number of deaths in prisons is portrayed as the author states that the number of deaths from natural causes is very high, which shows that, either for reasons of illness or any other cause considered natural, the person deprived of liberty suffers a total disregard of the State with respect to conditions inside the prisons. 


\section{Conclusions}

The results of this study showed how serious the situation is and the health conditions of inmates in a maximum security prison. The reality experienced by these individuals, who live in overcrowded cells in stages in unsanitary conditions and inaccessibility to health services, and picture of state failure and the competent bodies.

Because it is a part of so large and important population, it is unacceptable that in the middle of the twenty-first century convicts are treated in the same manner of the fifteenth century convicts. More important than passing new laws would discuss the vulnerabilities that must be overcome. However, government indifference to public health and their meager incentives ultimately stifle the improvement of progress that need.

In this research, the profile of the prison population reflects in a large quantity of young people between 25 and 34 years, serving sentences of between 0 and 9, where the total sentence varies between 0 and 29 years. It was observed that some feathers reach more than 40 years, thus demonstrating that these inmates are responsible for crimes against the person, property and against the customs.

The level of education also showed attention, since more than half of the detainees were unable to complete the first phase of elementary school, and consequently said they earn "up to" a minimum wage, and many of them do not receive any income.

With regard to the health profile of this population, the survey confirmed that over $95 \%$ of the prison population suffered in their health-disease process, the most cited the skin disorders, respiratory disorders, infectious diseases, gastrointestinal disorders, cardiovascular disorders, osteo and sexually transmitted diseases.

Detainees complain about the lack of health care, both by the lack of doctors and other health pro- fessionals, and the lack of equipment and drugs. Therefore, it appears that there are numerous difficulties in prisons, for the development of health actions. Still, the situation is getting worse while the alarming and growing number of pathologies that affect these individuals.

The state inertia stands as the centerpiece of this problem. The connivance of the governed ratifies this omission. Violation of the existential minimum health constitutionally guaranteed is blatantly being violated, and the result is an increasingly difficult to achieve solution.

\section{References}

1. Wolff M P. Antologias de vidas e histórias na prisão: emergência e injunção de controle social (tese de doutorado). Espanha: Programa de Doctorado em Derechos Humanos e Liberdades Fundamentales; 2002.

2. Guimarães CF, Meneghel SN, Zwetsch BE, Silva LB, Grano MS, Siqueira TP, et al. Homens apenados e mulheres presas: estudo sobre mulheres de presos. Psicologia e Sociedade; 2006 (sep/ dec); 18.

3. BRASIL. Ministério da Justiça. Departamento Penitenciário Nacional. Levantamento Nacional de Informações Penitenciárias INFOPEN. Junho de 2014.

4. BRASIL. Ministério da Saúde. Portaria $n^{\circ}$ 240, de 31 de janeiro de 2007. Brasília, 2007.

5. Divinews. Maioria da população carcerária no Brasil tem menos de 24 anos. Reportagem do dia 21 de maio de 2009 (Cited 2010 June 01) Available from: http://beta.divinews.com/brasil/54geral/924-maioria-da-populacao-carceraria-no-brasil-temmenos-de-24-anos.html.

6. Pará. Defensoria Pública do Estado. Perfil dos presos no Brasil, DEPEN - 2010. Portal JusBrasil. 2010 abr 05. (cited 2012 June 08) Available from: http://www.jusbrasil.com.br/

7. Dassi MALM. A Pena de Prisão e a Realidade Carcerária Brasileira: Uma Análise Crítica. (dissertação). Marília: Centro Universitário Eurípides de Marília - UNIVEM; 2007.

8. Jornal Correio. Criminalidade cresce oito vezes mais que a população, na Paraíba. 2008 maio 31; (cited 2012 May 31) Available from: http://www.clickpb.com.br/

9. Assis RD. A realidade atual do Sistema Penitenciário Brasileiro. (monografia)(internet). Faculdade Metropolitana IESB (Instituto de Educação Superior de Brasília; 2001.(cited 2010 June 01). Available from: http:/br.monografias.com/trabalhos908/arealidade-atual/a-realidade-atual.shtml 
10. Heukelbach J, Oliveira FASDe, Feldmeier H. Ectoparasitoses e saúde pública no Brasil: desafios para controle. Cad. Saúde Pública, 2003; 19 (5).

11. Nossa Casa. Assistência os presos: Denúncia feita pelos presos da Cadeia Pública de Leopoldina-MG. 2009 out 17. (cited 2012 May 31). Available from: http://www.nossacasa.net/ recomeco/0076.htm

12. Sánchez AR, Massari V, Gerhart G, Barreto AW, Cesconi V, Pires J, et al. A tuberculose nas prisões do Rio de Janeiro, Brasil: uma urgência de saúde pública. Cad. Saúde Pública; 2007; 23(3): 545-552.

13. Miranda AE, Zago, AM. Prevalência de infecção pelo HIV e sífilis em sistema correcional para adolescentes. Jorn bras de Doenças Sexualmente Transmissíveis. 2001; 13(4):35-39.

14. Brasil. Ministério da Saúde. Programa Nacional de Atenção Integral à Saúde do Homem. Brasília, 2008.

15. Carvalho ML, Valente JG, Assis SG, Vasconcelos, AGG. Perfil dos Internos no Sistema Prisional do Rio de Janeiro: Especificidades de Gênero no Processo de Exclusão Social. Ciên. Saúde Coletiva, 2006 april-june; 11(02).

16. Kuehne M. Privatização dos presídios. Rev. Cej; 2001; 15: 12-29.

17. Lima M. Visita íntima à intimidade da mulher: a mulher no sistema prisional (dissertação de mestrado). São Paulo: Faculdade de Saúde Pública a USP; 2006.

18. Mattedi JC. Alerta para surto de tuberculose em presídios. 2007 jul 08; (cited 2012 Jul 28) Available from: http://www.direitos. org.br.

19. Oliveira $\mathrm{HC}$, et al. Assistência a saúde à mulher presa: um direito negado. In: Anais do II Seminário Nacional: gênero e práticas culturais - Culturas leituras e representações, 2009; Natal: Rio Grande do Norte: UFRN/UNIP.

20. Amoy RA, Kury CMH, Silva RAC. Implicações Jurídicas da AIDS no Direito Penitenciário Brasileiro (monografia). Campos dos Goytacazes: Faculdade de Direito de Campos; 2007.

21. Pastoral Carcerária Nacional/CNBB. Relatório sobre mulheres encarceradas no Brasil. São Paulo: Ática; 2007.

22. Pastoral Carcerária Nacional/CNBB. Pena de morte ilegal e extrajudicial. São Paulo: Ática; 2005.
Publish in International Archives of Medicine

International Archives of Medicine is an open access journal publishing articles encompassing all aspects of medical science and clinical practice. IAM is considered a megajournal with independent sections on all areas of medicine. IAM is a really international journal with authors and board members from all around the world. The journal is widely indexed and classified Q2 in category Medicine. 